\title{
Gangguan Pola Siklus Haid pada Pesenam di Kota Pekanbaru
}

\author{
M uhammad M uzakir Fahmi ${ }^{1}$, Syamsul Bahri Riva' ${ }^{2}{ }^{2}$, Nurlisis ${ }^{3}$ \\ 'Program Studi M agister Kesehatan M asyarakat,STIKes Hang Tuah Pekanbaru, Indonesia \\ 20 bstetri dan Ginekologi RSU D A rifin A chmad Pekanbaru, Indonesia \\ ${ }^{2,3}$ D osen Program Studi M agister Kesehatan M asyarakat STIKes H ang Tuah Pekanbaru, Indonesia \\ Correspondence Email : muhammadmuzakirfahmi1994@gmail.com
}

\begin{abstract}
The average menstrual cycle obtained in the average menstrual cycle survey results was 29.51 days. Some experienced menstrual cycles of more than 35 days (oligomenore) of 10.29\% and menstrual cycles of less than 21 days (polimenore) of 1.5\%. There are $26.47 \%$ with a duration of menstruation more than 8 days. Furthermore, in the turn of the pads with a mean of 2.99 times per day, replace the pads. But there are some excessive dressing changes (> 3 times), while guessing that you experience excessive menstruation with a percentage of $23.5 \%$. There were $63 \%$ of women having menstrual disorders with the highest type of disorder $91.7 \%$ of other disorders related to menstruation, followed by menstrual disorders 25\%, and menstrual cycle disorders 5\%. With the average duration of menstruation obtained at 7.16 days which still includes the normal range of 2 to 8 days. Then research was conducted to find out the dominant factors associated with menstrual cycle pattern disorders. With the aim of analyzing the factors associated with menstrual cycle pattern disturbances in gymnasts in the city of Pekanbaru in 2018. This type of cross-sectional analytic study used a sample of 210 gymnasts in the city of Pekanbaru with inclusion and exclusion criteria. Statistical test uses Bivariate (chi square) and Simple Linear Multivaritic Regression. Variables that are significantly associated with p-value 0.20 is 2.7 times the disease history variable at risk of menstrual cycle pattern disorders.
\end{abstract}

Key words : Menstrual Disorders, Gymnasts, M enstrual Cycle Patterns, Women

\begin{abstract}
Abstrak
Rerata siklus haid wanita yang didapatkan pada hasil survei rerata siklus haid sebesar 29,51 hari. Ada yang men galami siklus haid lebih dari 35 hari (oligomenore) sebesar 10,29\% dan siklus haid kurang dari 21 hari (polimenore) sebesar 1,5\%. A da sebesar $26,47 \%$ dengan durasi haid lebih dari 8 hari. Selanjutnya dalam pergantian pembalut dengan rerata 2,99 kali per hari mengganti pembalut. Tetapi ada beberapa menganti pembalut secara berlebihan ( $>3$ kali) dugaan sementara mengalami pendarahaan haid secara berlebihan dengan persentase sebesar $23,5 \%$. Didapatkan $63 \%$ wanita mengalami gangguan haid dengan jenis gangguan terbanyak $91,7 \%$ gangguan lain yang berhubungan dengan haid, diikuti gangguan lama haid $25 \%$, dan gangguan siklus haid $5 \%$. Dengan rerata durasi haid yang didapatkan sebesar 7,16 hari yang masih termasuk rentang normal yaitu 2 sampai 8 hari. M aka dilakukan penelitian untuk mengetahui faktor dominan yang berhubungan dengan gangguan pola siklus haid. Dengan tujuan menganalisis faktor-faktor yang berhubungan dengan gangguan pola siklus haid pada pesenam di kota Pekanbaru tahun 2018. Jenis penelitian menggunakan analytic cross-sectional sampel yang digunakan yaitu 210 orang pesenam di kota Pekanbaru dengan kriteria insklusi dan ekslusi. Uji statistik menggunakan Bivariat (chi square) dan M ultivarit Regresi Linear Sederhana. Variabel yang berhubungan signifikan dengan $p$-value 0,20 yaitu variabel riwayat penyakit sebanyak 2,7 kali berisiko gangguan pola siklus haid.
\end{abstract}

Kata kunci : Gangguan Haid, Pesenam, Pola Siklus H aid, W anita

\section{Introduction}

Wanita yang mengikuti olahraga senam di Kota Pekanbaru akan memasuki masa pra-menopuase. Salah satu tanda awal pra-menopause adalah haid menjadi tidak teratur yang disebabkan oleh fluktuasi produksi hormon saat jumlah sel telur yang dilepaskan menurun. Siklus haid kadang memendek, memanjang, dan atau tidak mengalami haid sama sekali (Ghani, 2009). Hasil survei juga didapatkan

Received: 3 A pril 2020, Accepted : 17 M ay 2020 - M ay 2020 - Jurnal Photon V ol.10 No.2

DOI : https://doi.org/10.37859/jp.v10i2.1892

PHOTON is licensed under a Creative Commons Attribution-ShareAlike 4.0 International License 


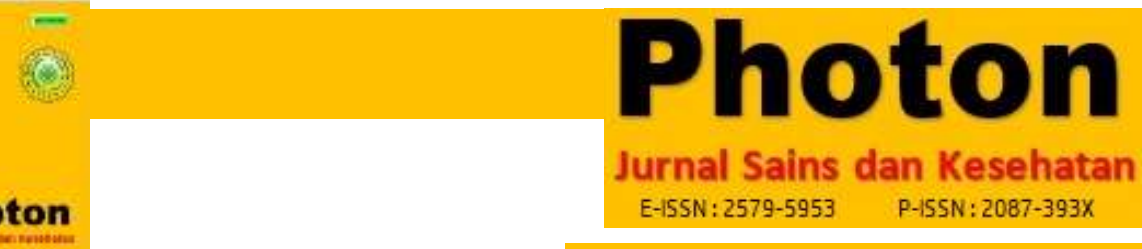

http://ejurnal.umri.ac.id/index.php/photon

selama mengikuti senam wanita yang mengikuti senam mengalami stres. Adapun faktor lain yang berhubungan dengan cepatnya menopuaseadalah usia menarcheyang lebih cepat dialami (W inarto et al., 2007).

Usia menarchewanita yang berolahraga senam di Kota Pekanbaru dengan rerata 12,93 tahun hal tersebut sesuai dengan rerata dari Kemenkes yaitu usia 13 tahun dengan rentang usia 9-20 tahun (Zalmi, Harahap $\&$ Desfita, 2017) dengan pengalaman mengalami nyeri haid dan riwayat mengkomsi obat anti nyeri. Adapun rerata siklus haid wanita yang didapatkan pada survei awal sebesar 29,51 hari yang masih termasuk nilai rerata yaitu 21 sampai 35 hari (Olivia, 2013). Tetapi ada yang mengalami siklus haid lebih dari 35 hari (oligomenore) sebesar 10,29\% dan siklus haid kurang dari 21 hari (polimenore) sebesar 1,5\%. Sedangkan hasil penelitian Sianipar et al., (2009) didapatkan 63\% wanita mengalami gangguan haid dengan jenis gangguan terbanyak $91,7 \%$ gangguan lain yang berhubungan dengan haid, diikuti gangguan lama haid $25 \%$, dan gangguan siklus haid $5 \%$. Dengan rerata durasi haid yang didapatkan sebesar 7,16 hari yang masih termasuk rentang normal yaitu 2 sampai 8 hari (W inarto et al., 2007), tetapi ada sebesar $26,47 \%$ dengan durasi haid lebih dari 8 hari. Selanjutnya dalam pergantian pembalut dengan rerata 2,99 kali per hari mengganti pembalut, hal ini juga masih dalam rentang normal penggantian pembalut yaitu 1 sampai 3 kali mengganti pembalut per hari. Tetapi ada beberapa menganti pembalut secara berlebihan (lebih dari 3 kali mengganti pembalut) dugaan sementara mengalami pendarahaan haid secara berlebihan dengan persentase sebesar $23,5 \%$.

Siklus haid yang tidak teratur dalam waktu lama merupakan tanda-tanda adanya penyakit pada sistem reproduksi seperti fibroid, kista, endometriosis, polip, sidrom polikistik ovarium, infeksi pada saluran reproduksi maupun kelainan genetik (Susilowati and Prasetyo, 2012). Banyaknya wanita mulai menyadari perubahan siklus haidnya tanpa menyadari artinya perubahan siklus haid yang dialaminya. Penelitian ini bertujuan untu menganalisis dan mengetahui faktor-faktor yang berisiko terhadap gangguan pola siklus haid pada pesenam di kota Pekanbaru.

\section{The M ethods}

Jenis penelitian yang digunakan adalah kuantitatif analitik observasional dengan jenis studi penampang analitik (analytic cross-sectional). Lokasi penelitian dilakukan di tujuh M egagym yang ada di Pekanbaru (N eo Fitnes Pekanbaru, Go Fitnes Pekanbaru, FitBeat Pekanbaru, Pitstop Studio Pekanbaru, Club Her Best The Peak A partement Pekanbaru, Sanggar Senam LG Pekanbaru, dan LKP Senam Pesona Pekanbaru. Subjek penelitian ini yaitu wanita pesenam yang mengalami haid dengan jumlah 210 sampel. Teknik pengambilan sampel menggunakan kriteria inklusi dan eklusi. Analisis data dilakukan secara multivariat dengan metode regresi logistik ganda.

\section{Result and Discussion}

\section{Varibel yang berhubungan signifikan dengan pola siklus haid}

\section{Riwayat Penyakit}

Dari hasil permodelan multivariat didapatkan dari variabel riwayat penyakit dengan nilai OR 2,761 artinya variabel riwayat penyakit lebih berisiko pada gangguan pola siklus haid sebanyak 2,7 kali dibandingkan dengan yang tidak mempunyai riwayat penyakit pada pesenam di kota Pekanbaru tahun 2018. Penelitian lain menyebutkan Adanya penyakit-penyakit endokrin seperti diabetes, hipotiroid, serta hipertiroid yang berhubungan dengan gangguan menstruasi. Dari penelitian Milanti, Fransiska and Nugroho, (2017) bahwa riwayat penyakit terutama penyakit endokrin akan sangat berpengaruh terhadap gangguan pola siklus haid pada wanita dengan 2,6 kali berisiko gangguan pola siklus haid. Dari beberapa penelitian juga didapatkan adanya hubungan obesitas (Benaino, Ticoalu, \&

Received: 3 A pril 2020, Accepted : 17 M ay 2020 - M ay 2020 - Jurnal Photon Vol.10 No.2

DOI : https://doi.org/10.37859/jp.v10i2.1892

PHOTON is licensed under a Creative Commons Attribution-ShareAlike 4.0 International License 


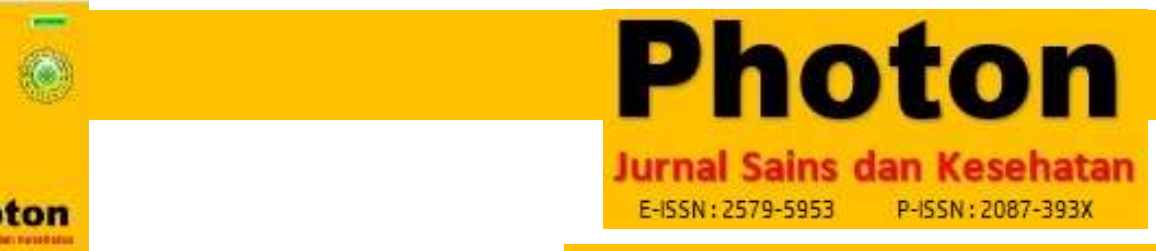

http://ejurnal.umri.ac.id/index.php/photon

W ongkar, 2014), olahraga , dan stress. Dari hasil analisa bahwa riwayat penyakit sangat berpengaruh terhadap gangguan pola siklus haid.

\section{Pekerjaan}

Dari hasil permodelan multivariat didapatkan dari variabel riwayat penyakit dengan nilai OR 0,034 artinya variabel pekerjaan IRT lebih berisiko pada gangguan pola siklus haid sebanyak 4 kali dibandingkan dengan yang tidak mempunyai riwayat penyakit pada pesenam di kota Pekanbaru. Dalam penelitian Putri \& Sudhana (2013) beban kerja yang berat berhubungan dengan jarak menstruasi yang panjang dibandingkan dengan beban kerja ringan dan sedang. Perubahan rutinitas dalam hidup dapat berpengaruh pada kondisi fisik. Misalnya mereka yang harus berganti jam kerja dari pagi menjadi malam. $\mathrm{Hal}$ ini biasa terjadi sehingga tubuh menyesuaikan dengan siklus atau rutinitas baru yang dapat menggangu pada kesehatan tubuh. Menurut Putri \& Sudhana (2013) tuntutan kerja yang terlalu banyak dan beban kerja yang berat dapat menimbulkan stres. Oleh karena itu perlu adanya kekuatan fisik maupun mental untuk bisa melakukan seluruh pekerjaan rumah tangga dengan baik. Sebuah penelitian yang dilakukan oleh $\mathrm{N}$ ational Institute for $\mathrm{Child} \mathrm{H}$ ealth and Human Development Study of Early Child Care and Youth Development yang melibatkan 1.300 perempuan menunjukkan bahwa perempuan yang bekerja di luar rumah walau hanya bekerja part time memiliki kesehatan yang lebih baik dan lebih sedikit mengalami gejala depresi dibandingkan dengan perempuan yang mencurahkan waktunya untuk mengurusi rumah dan keluarga.

Dari hasil analisa beberapa penelitian bahwa adanya hubungan yang signifikan pekerjaan yang berlebih terhadap gangguan pola siklus haid terutama yang bekerja selain IRT dangan 0,04 kali berisiko mengalami gangguan pola siklus haid. $\mathrm{H}$ asil lain dalam penelitian bahwa adanya hubungan antara olahraga dengan pekerjaan Putri \& Sudhana (2013). H asil yang didapatkan pada uji statistik bahwa adanya hubungan yang signifikan antara pekerjaan dengan stress dengan 0,45 kali berisiko mengal ami stress apabila dengan beban pekerjaan berlebih.

\section{Variabel confounding dengan pola siklus haid \\ 1. Pendidikan}

Pendidikan secara umum adalah segala upaya di rencanakan untuk mempengaruhi orang lain baik individu maupun masyarakat sehingga mereka melakukan apa yang di harapkan oleh pelaku pendidikan. Dari batasan di atas tersirat unsur-unsur pendidikan yakni infut, proses dan output. Sedangkan pendidikan kesehatan adalah aplikasi atau penerapan pendidikan dalam bidang kesehatan. Perlunya tingkat pendidikan menandakan semakin tingginya pengetahuan untuk mengetahui jenis dan cara pengobatan suatu penyakit (Y ulianti, 2010).

M enurut Kemdikbud (2016) agar meningkatkan akses bagi anak usia 6 (enam) sampai dengan 21 (dua puluh satu) tahun untuk mendapatkan layanan pendidikan sampai tamat satuan pendidikan menengah dalam rangka mendukung pelaksanaan pendidikan menengah universal/rintisan wajib belajar 12 (dua belas) tahun.

Dengan pendidikan tinggi seseorang akan cenderung mendapatkan informasi, baik dari orang lain maupun dari media massa, sebaliknya tingkat pendidikan yang kurang akan menghambat perkembangan dan sikap seseorang terhadap nilai-nilai yang baru diperkenalkan. Pendidikan seseorang terkait dengan kemampuan seseorang untuk mempelaari perilaku yang berhubungan dengan perilaku yang sehat. Tetapi perilaku juga dipengaruhi faktor, tidak hanya pendidikan merupakan predisposisi, tetapi faktor enabling, dan reinforcing, yang mempunyai kaitan dengan lain. Secara umum pendidikan sesuai dengan Peraturan Menteri Pendidikan Dan Kebudayaan Republik Indonesia Nomor 19 Tahun 2016 Tentang Program Indonesia Pintar pendidikan rendah (lulusan

Received: 3 A pril 2020, Accepted : 17 M ay 2020 - M ay 2020 - Jurnal Photon Vol.10 No.2

DOI : https://doi.org/10.37859/jp.v10i2.1892

PHOTON is licensed under a Creative Commons Attribution-ShareAlike 4.0 International License 
dibawah Sekolah Menengah Atas/ SMA/ Sederajat) sedangkan pendidikan tinggi adalah lulusan Perguruan Tinggi.

\section{Status perkawinan}

A danya pengaruh siklus haid terhadap status perkawinan seseorang. W anita yang single atau janda lebih berisiko terhadap gangguan pola siklus haid. Dengan kesimpulan bahwa seks secara aktif akan menurunkan risiko gangguan pola siklus haid.

\section{Pola makan}

M enurut Kalangit (2016) diet yang baik adalah diet yang menekankan pada perubahan dalam jenis makanan, jumlah, dan seberapa sering seseorang makan, dan ditambah dengan program. Diet dapat memengaruhi fungsi menstruasi. Vegetarian berhubungan dengan anovulasi, penurunan respons hormone pituitary, fase folikel yang pendek, tidak normalnya siklus menstruasi (kurang dari 10 kali/tahun). Diet rendah lemak berhubungan dengan panjangnya siklus menstruasi dan periode perdarahan. Diet rendah kalori seperti daging merah dan rendah lemak berhubungan dengan amenorrhea. H asil analisa bahwa pola makan tidak mempengaruhi gangguan pola siklus haid, tetapi pada diit yang dilakukan selain daging yaitu orang dengan vegetarian penelitian terkait bahwa sangat mempengaruhi gangguan pola siklus haid.

4. Jumlah anak

Paritas atau jumlah anak kelahiran hidup dan mati dari suatu kehamilan 28 minggu keatas yang pernah dialami ibu. Paritas sebanyak 2-3 kali merupakan paritas paling aman ditinjau dari sudut kematian maternal. Dari penelitian Putra et al. (2016) mendapatkan hasil bahwa jumlah paritas ada hubungan dengan siklus haid. Semakin banyak paritas siklus haid menjadi lebih teratur.

5. Status gizi

M enurut Kalangit (2016) diet yang baik adalah diet yang menekankan pada perubahan dalam jenis makanan, jumlah, dan seberapa sering seseorang makan, dan ditambah dengan program.

Diet dapat memengaruhi fungsi menstruasi. Vegetarian berhubungan dengan anovulasi, penurunan respons hormone pituitary, fase folikel yang pendek, tidak normalnya siklus menstruasi (kurang dari 10 kali/tahun). Diet rendah lemak berhubungan dengan panjangnya siklus menstruasi dan periode perdarahan. Diet rendah kalori seperti daging merah dan rendah lemak berhubungan dengan amenorrhea. Hasil analisa didapatkan bahwa status gizi tidak berpengaruh pada gangguan pola siklus haid sesuai dengan beberapa penelitian terkait bahwa yang sangat mempengaruhi bukan dari status gizi (lingkar lengan dan lingkar perut) tetapi berpengaruh terhadap diit yang dilakukan terutema diit terhadap makanan berdaging (vegetarian).

6. Usia

M ilanti, Fransiska and N ugroho, (2017) semua responden berusia lebih dari 22 tahun mempunyai siklus menstruasi teratur. Responden berusia 19-22 tahun mempunyai siklus teratur sebesar 65,1\% (97 orang) dan $34,9 \%$ (52 orang) mempunyai siklus tidak teratur. Responden yang berusia 17 tahun sampai 18 tahun mengalami siklus teratur sebanyak $64,3 \%$ dan tidak teratur sebanyak 35,7\%. Dengan analisa bahwa makin bertambahnya umur akan sangat berpengaruh terhadap gangguan pola siklus haid terutama pada usia $>35$ tahun.

\section{Pengetahuan}

Dari penelitian lain menyebutkan bahwa pengetahuan yang baik sangat berpengaruh untuk menjaga kesehatan reproduksi wanita (Kalangit, 2016). Oleh sebab itu perlunya peningkatan pengetahuan untuk meningkatkan pengetahuan mengenai kesehatan reproduksi terutama menjaga kesehatan reproduksi wanita.

8. IMT

Received: 3 A pril 2020, Accepted : 17 M ay 2020 - M ay 2020 - Jurnal Photon V ol.10 No.2

DOI : https://doi.org/10.37859/jp.v10i2.1892

PHOTON is licensed under a Creative Commons Attribution-ShareAlike 4.0 International License 


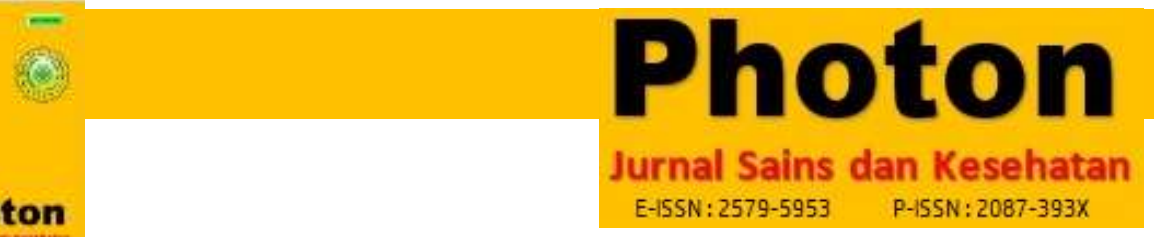

http://ejurnal.umri.ac.id/index.php/photon

IMT merupakan hasil statistik dari Berat Badan dan tinggi badan. Dalam penelitian terdahulu bahwa Berat badan dan perubahan berat badan memengaruhi fungsi menstruasi. Penurunan berat badan akut dan sedang menyebabkan gangguan pada fungsi ovarium, tergantung derajat tekanan pada ovarium dan lamanya penurunan berat badan. Kondisi patologis seperti berat badan yang kurang/kurus dan anorexia nervosa yang menyebabkan penurunan berat badan yang berat dapat menimbulkan amenorrhea (Islami, 2016). Sedangkan penelitian Susanti (2015) didapatkan adanya hubungan yang bermakna antara berat badan dengan gangguan siklus menstruasi pada wanita usia subur dengan nilai $p$ - value $=0,006(<0,05)$.

Memiliki IMT tinggi atau rendah dapat menyebabkan tidak terjadinya menstruasi dan siklus menstruasi tidak teratur (M ilanti et al., 2017). Pada penelitian Milanti, Fransiska \& N ugroho (2017) didapatkan responden dengan siklus menstruasi teratur paling banyak mempunyai IM T normal yaitu sebesar 75\% (93 orang). Hal ini sesuai dengan penelitian $\mathrm{H}$ arahap (2013) yang mendapatkan wanita dengan IMT normal mempunyai siklus menstruasi teratur. Responden dengan IMT lebih yang mengalami siklus tidak teratur sebesar $66,7 \%$ (39 orang) sedangkan sisanya $33,3 \%$ (13 orang) mengalami siklus teratur. Penelitian (Priani, 2016) yang mendapatkan sebesar $51,4 \%$ perempuan dengan berat badan over-weight dan 65,9\% perempuan dengan berat badan obese mengalami siklus menstruasi tidak teratur. M emiliki IM T tinggi dapat menyebabkan tidak terjadinya menstruasi, siklus menstruasi tidak teratur, dan nyeri menstruasi. Lebih panjangnya siklus menstruasi disebabkan oleh jumlah estrogen meningkat dalam darah akibat meningkatnya jumlah lemak dalam tubuh sehingga kadar estrogen yang tinggi tersebut akan memberikan umpan balik negatif terhadap sekresi GnRH. Umpan balik sekresi hormon $\mathrm{GnRH}$ melalui sekresi protein inhibitor yang dapat menghambat hipofisis anterior untuk mensekresikan hormon FSH. Terhambatnya sekresi hormon FSH menyebabkan terganggunya proliferasi folikel sehingga tidak terbentuk folikel yang matang sehingga menyebabkan lebih panjangnya siklus menstruasi (Milanti et al., 2017).

Analisa dari beberapa penelitian bahwa IMT yang tinggi tidak akan terjadi siklus haid, hal ini sesuai dengan penelitian bahwa IM T yang tinggi tidak mempengaruhi gangguan pola siklus haid. $\mathrm{Hal}$ ini sesuai dengan penelitian Sianipar et al., (2009)Tidak didapatkan hubungan bermakna $(p=0,191)$ antara IMT dengan gangguan menstruasi. Walaupun demikian, siswi dengan gangguan menstruasi memiliki rerata IMT lebih tinggi (IMT =22,3) dibandingkan siswi yang tidak mengalami gangguan menstruasi (IMT =20,8). H asil tersebut memiliki pola serupa dengan penelitian Lee yang mendapatkan hubungan bermakna antara IMT yang tinggi dengan sindrom pramenstruasi. Harlow dan Rowland juga mendapatkan hubungan bermakna antara tingginya IMT dan perpanjangan siklus menstruasi. Gangguan menstruasi juga dapat terjadi pada wanita dengan IMT rendah, seperti yang didapatkan oleh Hirata yaitu adanya peningkatan risiko ( $O R=1,3$ dengan $95 \% \mathrm{Cl}=1,1-1,6)$ pada wanita dengan IMT rendah untuk mengalami nyeri menstruasi. $\mathrm{H}$ al tersebut menunjukkan bahwa jenis gangguan menstruasi yang terjadi bergantung pada nilai IM T (underweight atau overweight).

\section{Usia menarche}

Safitri (2014) di Pekanbaru dimana sebesar $71,4 \%$ wanita mendapat menstruasi pertama kali pada usia medium. Berbeda dengan penelitian Ali (2011) di Sudan mendapatkan sebesar $76,4 \%$ wanita mengalami late menarke. Perbedaan tersebut dapat disebabkan oleh beberapa faktor seperti genetik, status sosial, dan status gizi (M ilanti et al., 2017). Ketidakteraturan siklus menstruasi terjadi terutama pada 2 tahun pertama setelah menarke dan sebelum menopause. Hasil penelitian terhadap 4000 wanita, hanya $3 \%$ diantaranya yang mempunyai siklus menstruasi yang teratur. $\mathrm{H}$ ampir semua wanita mengalami perubahan siklus menstruasi setiap bulannya (Milanti et al., 2017). U sia menarke yang terlambat berhubungan dengan gangguan siklus menstruasi. Tingkat usia menarke di Indonesia sangat bervariasi menurut Riskesdas 2010 dalam Safitri (2014) menunjukkan rata-rata usia menarke di

Received: 3 A pril 2020, Accepted : 17 M ay 2020 - M ay 2020 - Jurnal Photon V ol.10 No.2

DOI : https://doi.org/10.37859/jp.v10i2.1892

PHOTON is licensed under a Creative Commons Attribution-ShareAlike 4.0 International License 


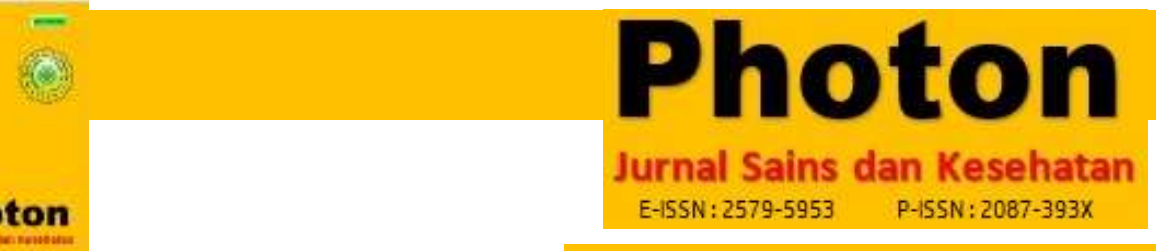

http://ejurnal.umri.ac.id/index.php/photon

Indonesia adalah 13 tahun (20,0\%). Sebagian besar penyimpangan terlambatnya menarke bisa bersifat sementara yang merupakan gejala dari aksis hipotalamus-hipofisis-ovarium yang belum matang (M ilanti et al., 2017).

Perempuan yang mengalami menstruasi pertama pada usia 11 tahun atau kurang akan memiliki risiko lebih tinggi untuk mengalami siklus menstruasi yang memanjang. $\mathrm{Hal}$ ini juga ditemukan pada perempuan yang mengalami menstruasi pertama pada usia 14 tahun keatas. Usia menarke berhubungan dengan waktu yang dibutuhkan untuk mencapai siklus ovulasi yang teratur. Jika wanita mengalami early menarke, $50 \%$ siklus ovulasi terjadi pada tahun pertama setelah menarke, sedangkan wanita dengan late menarke membutuhkan 8-12 tahun untuk ovulasi sepenuhnya (M ilanti et al., 2017).

Dengan beberapa penelitian terkait bahwa usia menarche sangat berhubungan dengan gangguan pola siklus haid terutama $<13$ tahun yang akan jauh lebih berisiko pada gangguan pola siklus haid. Dalam penelitian (M ilanti et al., 2017) menyebutkan bahwa ada status gizi yang sangat mempengaruhi usia menarche tetapi pada penelitian ini tidak terhadap hubungan yang signifikan pada usia menarche dengan status gizi dengan hasil uji statistik p value 1,000 tetapi akan berisiko 1,05 kali mengalami usia menrache $<13$ tahun apabila mengalami gangguan status gizi yang dilihat dari lingkar lengan dan lingkar perut.

\section{Variabel yang tidak berhubungan signifikan}

\section{Stress}

Stres dapat menginduksi perubahan siklus hormonal melalui mekanisme fisiologis aktivasi berlebihan dan berkepanjangan sumbu adrenal hipotalamus-hipofisis, meningkatkan corticotrophin releasing hormone ( $\mathrm{CRH})$, dan glukokortikoid (kortisol). Kortisol ini meningkatkan fungsi otak dan memperlambat atau menghentikan fungsi tubuh non-esensial, seperti pertumbuhan sel, pencernaan, dan reproduksi. A kibatnya sintesis dan metabolisme gonadotropin dan estrogen ditekan, sehingga mengganggu fisiologi menstruasi wanita (M ilanti et al., 2017).

Yamamoto (2002) yang mendapatkan $74 \%$ responden yang mengalami stres berat mempunyai siklus menstruasi tidak teratur dan $40 \%$ stres ringan mengalami menstruasi tidak teratur. Sri Wahyuni juga melakukan penelitian pada mahasiswi kebidanan Klaten dan hasilnya responden dengan stres ringan mengalami siklus menstruasi teratur sebesar $28,9 \%$ dan hanya sebesar 5,3\% mengalami siklus tidak teratur. Penelitian Nurlaila mendapatkan sebesar $72 \%$ responden yang tidak stres mempunyai siklus menstruasi teratur dan $62,7 \%$ responden yang mengalami stres mempunyai siklus tidak teratur (M ilanti et al., 2017).

\section{Penggunaan alat kontrasepsi}

Dalam penelitian terkait mengenai gangguan haid bahwa penyebab dismenorea sekunder lainnya yaitu karena pemakaian kontrasepsi Intra Uteri Device (IUD), dismenorea sekunder lebih jarang ditemukan pada remaja, biasanya terjadi pada usia 25 tahun. Dismenorea primer merupakan nyeri haid karena aktivitas uterus, tanpa adanya kondisi patologis dari pelvis. Beberapa faktor penyebab dismenorea primer, antara lain faktor kejiwaan, faktor konstitusi, faktor obstruksi kanalis servikalis (M anurung, U tami, \& HD , 2015). Dalam penelitian lain juga menyebutkan kontrasepsi oral, olahraga dan menikah dilaporkan menurunkan kemungkinan gangguan haid yaitu dismenorea (Olivia, 2013)

Penelitian Sianipar et al., (2009) di Kecamatan Pulo Gadung, Jakarta Timur yang sedang menderita penyakit berat yang dapat mempengaruhi siklus menstruasi (tuberkulosis, hipertiroidisme, hipotiroidisme, lupus eritematosus sistemik, dan gangguan koagulasi darah), mengonsumsi obatobatan hormonal (termasuk kontrasepsi) dan yang tidak hadir saat pengambilan sampel. H asil analisa bahwa penggunaan kontrasepsi $>1$ tahun berisiko 0,9 kali mengalami gangguan pola siklus haid. $\mathrm{Hal}$

Received: 3 A pril 2020, Accepted : 17 M ay 2020 - M ay 2020 - Jurnal Photon V ol.10 No.2 DOI : https://doi.org/10.37859/jp.v10i2.1892

PHOTON is licensed under a Creative Commons Attribution-ShareAlike 4.0 International License 


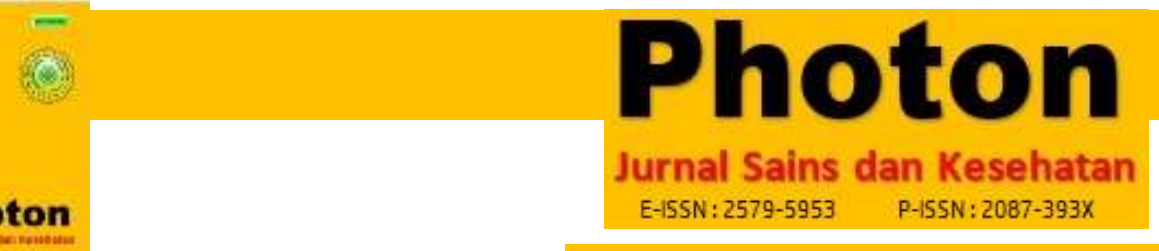

http://ejurnal.umri.ac.id/index.php/photon

lain juga menyebutkan bahwa hal yang sangat mengganggu gangguan pola siklus haid pada dismenore terhadap olahraga, status perkawinan, (Olivia, 2013) dan riwayat penyakit (Sianipar et al., 2009).

\section{Beban olahraga}

Semakin banyak wanita yang menyukai kegiatan fisik dengan tingkat penampilannya yang terus meningkat. Walaupun terdapat masalah kesehatan khusus yang berhubungan dengan fungsi reproduksinya yang unik, tetapi manfaatnya bagi kesehatan dan pergaulan sosial, jauh melebihi pengaruh-pengaruh merugikan yang terjadi selama ini (Raswin, 2014). Hasil penelitian Milanti, Fransiska \& Nugroho (2017) mendapatkan hasil sebanyak 66,7\% perempuan dengan aktivitas fisik tinggi mengalami siklus menstruasi tidak teratur.

Asmarani tahun 2010 mendapatkan sebesar 28\% wanita dengan aktivitas tinggi mengalami ketidakteraturan siklus menstruasi. Penelitian Rich-Edwards dalam Sianipar (2009) menyebutkan bahwa pada wanita Amerika, peningkatan aktivitas fisik justru berhubungan dengan risiko berkurangnya kejadian ovulasi. Penambahan tiap jam aktivitas fisik intensitas berat per minggu terkait dengan penurunan $7 \%$ risiko terjadinya masalah ovulasi (M ilanti et al., 2017). Tingkat aktivitas fisik yang sedang dan berat dapat membatasi fungsi menstruasi (W inarto et al., 2007).

$\mathrm{H}$ al lain dalam penelitian ini yaitu beban olahraga dibagi menjadi empat keompok yaitu aerobic, zumba, yoga, dan pilates. Penelitian lain juga menyebutkan Melakukan senam aerobik dengan frekuensi yang lebih teratur dapat membantu menurunkan gejala keluhan gejala prahaid, karena pada saat melakukan senam aerobik akan menimbulkan rasa senang karena gerakan-gerakan di dalam senam aerobik menyenangkan, sehingga wanita yang me- lakukan senam dapat mengurangi stres. Senam aerobik dibutuhkan banyak energi, sehingga banyak mengoksidasi karbohidrat dan lemak untuk memenuhi energi yang dibutuhkan. Senam aerobik dapat menjaga berat badan tidak bertambah (Noor \& Norfitri, 2015). Jenis olahraga yang dipakai dalam penelitian Kurniawan, Trisetiyono \& Pramono (2016) adalah olahraga aerobik dan anaerobik. Kejadian siklus haid yang tidak teratur pada masing-masing olahraga yaitu aerobik sebesar $48.75 \%$ dan anaerobik sebesar $28.75 \%$. Persentase siklus menstruasi tidak teratur paling tinggi pada olahraga aerobik, hal tersebut kemungkinan disebabkan karena sebagian besar subyek penelitian pada jenis olahraga ini melakukan latihan dengan frekuensi dan durasi yang paling banyak dibandingkan olahraga lainnya. A nalisa penelitian terkait bahwa beban olahraga tidak berpengaruh terhadap gangguan pola siklus haid, tidak sesuai dengan penelitian terkait bahwa beban olahraga sangat berpengaruh terhadap gangguan pola siklus haid terutama beban olahraga yang berlebihan dan beban olahraga tidak memiliki hubungan sebab akibat dengan gangguan pola siklus haid pada pesenam di kota Pekanbaru tahun 2018.

Received: 3 A pril 2020, Accepted : 17 M ay 2020 - M ay 2020 - Jurnal Photon V ol.10 No.2

DOI : https://doi.org/10.37859/jp.v10i2.1892

PHOTON is licensed under a Creative Commons Attribution-ShareAlike 4.0 International License 
http://ejurnal.umri.ac.id/index.php/photon

Tabel 1 Faktor-Faktor yang Berhubungan dengan Gangguan Pola Siklus H aid Pada Pesenam Di Kota Pekanbaru

\begin{tabular}{|c|c|c|c|c|c|c|c|c|c|}
\hline \multirow{3}{*}{ No. } & \multirow{3}{*}{ Variabel } & \multicolumn{4}{|c|}{ Pola Siklus H aid } & \multirow{2}{*}{\multicolumn{2}{|c|}{ Jumlah }} & \multirow{3}{*}{$\mathrm{P}$-value } & \multirow{3}{*}{ OR } \\
\hline & & \multicolumn{2}{|c|}{ Gangguan } & \multicolumn{2}{|c|}{ Tidak Gangguan } & & & & \\
\hline & & $\mathrm{n}$ & $\%$ & $\mathrm{n}$ & $\%$ & $\mathrm{n}$ & $\%$ & & \\
\hline \multirow[t]{4}{*}{1.} & Usia M enarche & & & & & & & & \\
\hline & - Berisiko & 50 & 64,9 & 27 & 35,1 & 77 & 36,7 & 0,057 & $\begin{array}{l}1,824 \\
1,2,252\end{array}$ \\
\hline & - Tidak Berisiko & 67 & 50,4 & 66 & 49,6 & 133 & 63,3 & & \\
\hline & & 117 & 55,7 & 93 & 44,3 & 210 & 100 & & \\
\hline \multirow[t]{4}{*}{2.} & Riwayat Penyakit & & & & & & & & \\
\hline & - Berisiko & 71 & 67,6 & 34 & 32,4 & 105 & 50 & 0,001 & $\begin{array}{l}2,0 / 8 \\
1527-1608\end{array}$ \\
\hline & - Tidak Berisiko & 46 & 43,8 & 59 & 59 & 105 & 50 & & \\
\hline & & 117 & 55,7 & 93 & 44,3 & 210 & 100 & & \\
\hline \multirow[t]{4}{*}{3.} & Penggunaan Alat Kontrasepsi & & & & & & & & \\
\hline & - Berisiko & 59 & 44,8 & 85 & 55,2 & 154 & 73,3 & 0,000 & $0060-0305$ \\
\hline & - Tidak Berisiko & 48 & 85,7 & 8 & 14,3 & 56 & 26,7 & & \\
\hline & & 117 & 55,7 & 93 & 93 & 210 & 100 & & \\
\hline \multirow[t]{4}{*}{4.} & IMT & & & & & & & & \\
\hline & - Berisiko & 54 & 55,1 & 44 & 44,9 & 98 & 46,6 & 0,978 & 0,955 \\
\hline & - Tidak Berisiko & 63 & 56,3 & 49 & 43,8 & 112 & 53,4 & & \\
\hline & & 117 & 55,7 & 93 & 44,3 & 210 & 100 & & \\
\hline \multirow[t]{4}{*}{5.} & Status Gizi & & & & & & & & \\
\hline & - Berisiko & 36 & 64,3 & 20 & 35,7 & 56 & 26,6 & 0,177 & 1,622 \\
\hline & - Tidak Berisiko & 81 & 52,6 & 73 & 47,4 & 154 & 73,4 & & \\
\hline & & 117 & 93 & 93 & 44,3 & 210 & 100 & & \\
\hline \multirow[t]{4}{*}{6.} & Pola M akan & & & & & & & & \\
\hline & - Buruk & 58 & 59,2 & 40 & 40,8 & 98 & 46,6 & 0,419 & $\begin{array}{c}1,303 \\
0753-2752\end{array}$ \\
\hline & • Baik & 59 & 52,7 & 53 & 47,3 & 112 & 53,4 & & \\
\hline & & 117 & 55,7 & 93 & 44,3 & 210 & 100 & & \\
\hline \multirow[t]{4}{*}{7.} & Pekerjaan & & & & & & & & 0,048 \\
\hline & - Bekerja Salain IRT & 69 & 43,4 & 90 & 56,6 & 159 & 75,7 & 0,000 & $0,014-0,160$ \\
\hline & - Tidak Bekerja (IRT) & 48 & 94,1 & 3 & 5,9 & 51 & 24,3 & & \\
\hline & & 117 & 55,7 & 93 & 44,3 & 210 & 100 & & \\
\hline \multirow[t]{4}{*}{8.} & Beban Olahraga & & & & & & & & 1,560 \\
\hline & - Berisiko & 27 & 64,3 & 15 & 35,7 & 42 & 20 & 0,282 & $0,775-3,142$ \\
\hline & - Tidak Berisiko & 90 & 53,6 & 78 & 46,4 & 168 & 80 & & \\
\hline & & 117 & 55,7 & 93 & 44,3 & 210 & 100 & & \\
\hline \multirow[t]{4}{*}{9.} & Usia & & & & & & & & 0,712 \\
\hline & - Berisiko & 62 & 52,1 & 57 & 47,9 & 119 & 56,6 & 0,287 & $0,410-1,238$ \\
\hline & - Tidak Berisiko & 55 & 60,4 & 36 & 39,6 & 91 & 43,4 & & \\
\hline & & 117 & 55,7 & 93 & 44,3 & 210 & 100 & & \\
\hline \multirow[t]{4}{*}{10.} & Pendidikan & & & & & & & & \\
\hline & - Rendah & 12 & 44,4 & 15 & 55,6 & 27 & 12,8 & 0,291 & $\begin{array}{c}0,594 \\
02631341\end{array}$ \\
\hline & • Tinggi & 105 & 57,4 & 78 & 42,6 & 183 & 87,2 & & \\
\hline & & 117 & 55,7 & 93 & 44,3 & 210 & 100 & & \\
\hline
\end{tabular}

Received: 3 A pril 2020, Accepted : 17 M ay 2020 - M ay 2020 - Jurnal Photon Vol.10 No.2

DOI : https://doi.org/10.37859/jp.v10i2.1892

PHOTON is licensed under a Creative Commons Attribution-ShareAlike 4.0 International License 
$\underline{\text { http://ejurnal.umri.ac.id/index.php/photon }}$

11. Status Perkawinan

- Sudah pernah menikah

\begin{tabular}{ccccccc}
25 & 35,7 & 45 & 64,3 & 70 & 33,4 & 0,000 \\
92 & 65,7 & 48 & 34,3 & 240 & 66,6 & \\
\hline 117 & 55,7 & 93 & 44,3 & 210 & 100 &
\end{tabular}

0,290

- Menikah

12. Jumlah Anak

- Berisiko

$71 \quad 59,7 \quad 48$

40,3

119

56,7

0,239

1,447

- Tidak Berisiko

\begin{tabular}{|c|c|c|c|}
\hline 50,5 & 45 & 45 & 91 \\
\hline 55,7 & 93 & 44,3 & 210 \\
\hline
\end{tabular}

\begin{tabular}{|c|c|c|c|c|c|c|c|c|c|}
\hline \multirow[t]{3}{*}{13.} & Stress & 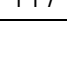 & 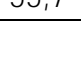 & & 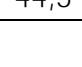 & & & \multirow{3}{*}{0,955} & \multirow{3}{*}{$\begin{array}{c}1,057 \\
0,610-1,830\end{array}$} \\
\hline & - Berisiko & 67 & 56,3 & 52 & 43,7 & 119 & 56,7 & & \\
\hline & \multirow[t]{2}{*}{ - Tidak Berisiko } & 50 & 54,9 & 41 & 45,1 & 91 & 43,4 & & \\
\hline & & 117 & 55,7 & 93 & 44,3 & 210 & 100 & & \\
\hline \multirow[t]{4}{*}{14.} & Pengetahuan & & & & & & & \multirow{3}{*}{0,032} & \multirow{3}{*}{$\begin{array}{c}0,106 \\
0.013-0,877\end{array}$} \\
\hline & • Rendah & 1 & 12,5 & 7 & 87,5 & 8 & 3,8 & & \\
\hline & \multirow[t]{2}{*}{ • Tinggi } & 116 & 57,4 & 86 & 42,6 & 202 & 96,2 & & \\
\hline & & 117 & 55,7 & 93 & 44,3 & 210 & 100 & & \\
\hline
\end{tabular}

Tabel $2 \mathrm{H}$ asil Permodelan M ultivariat A khir Faktor-Faktor Gangguan Pola Siklus H aid Pada Pesenam di Kota Pekanbaru Tahun 2018

\begin{tabular}{llcccc}
\hline \multirow{2}{*}{ No. } & \multirow{2}{*}{ Variabel } & \multirow{2}{*}{ P-value } & \multirow{2}{*}{ OR } & \multicolumn{2}{c}{$95 \% \mathrm{Cl}$} \\
\cline { 5 - 6 } & & & & Lower & Upper \\
\hline 1. & Riwayat Penyakit &, 020 & 2,761 & 1,173 & 6,496 \\
\hline 2. & Pola M akan &, 189 & 1,648 &, 782 & 3,470 \\
\hline 3. & Jumlah Anak &, 247 &,- 627 &,- 313 &, 789 \\
\hline 4. & IMT & $-1,648$ &, 672 &, 613 &, 447 \\
\hline 5. & Status Gizi &, 363 &, 339 &, 154 &, 826 \\
\hline 6. & U sia M enarche & 2,000 & 1,280 &, 491 & 3,336 \\
\hline 7. & Pendidikan &, 106 & 2,685 &, 731 &, 274 \\
\hline 8. & U sia &, 454 &, 083 & 2,486 &, 663 \\
\hline 9. & Pengetahuan & 1,540 &, 192 &, 020 & 1,850 \\
\hline 10. & Pekerjaan &, 000 &, 034 &, 006 &, 187 \\
\hline 11. & Status Perkawianan &, 156 &, 530 &, 221 & 1,273 \\
\hline
\end{tabular}

Omnimbus test $=<0,001$ Nagalkerke $R$ Square $=0,394$

Kesimpulan

Variabel yang berhubungan signifikan yaitu riwayat penyakit sebanyak 2,7 kali berisiko gangguan pola siklus haid pada pesenam di kota Pekanbaru tahun 2018 . Variabel yang dominan yaitu riwayat penyakit dan pekerjaan terhadap gangguan pola siklus haid pada pesenam di kota Pekanbaru tahun 2018. Variabel Confounding yaitu variabel pendidikan, status perkawinan, pola makan, jumlah anak, status gizi, usia, pengetahuan, IMT, dan usia menarche terhadap gangguan pola siklus haid pada pesenam di kota Pekanbaru tahun 2018. Variabel yang tidak berhubungan signifikan yaitu stress, penggunaan alat kontrasepsi, dan beban olahraga tidak memiliki hubungan sebab akibat dengan gangguan pola siklus haid pada pesenam di kota Pekanbaru tahun 2018.

Received: 3 A pril 2020, Accepted : 17 M ay 2020 - M ay 2020 - Jurnal Photon V ol.10 No.2 DOI : https://doi.org/10.37859/jp.v10i2.1892

PHOTON is licensed under a Creative Commons Attribution-ShareAlike 4.0 International License 


\section{Acknowledgement}

Terima kasih peneliti ucapkan kepada Pembimbing yang telah banyak membantu dalam menyelesaikan penelitian ini, kepada Bapak Dr. dr. Syamsul Bahri Riva'i, Sp.OG dan Ibu Nurlisis, SKM., M.Kes seterusnya kepada penguji dalam penelitian ini Bapak Dr. dr. Donel, Sp.OG (KFM) dan I bu drg. O ktavia Dewi, M .Kes., dan semua pihak yang terlibat dalam melancarkan dalam penelitian ini sampai selesai.

\section{References}

Benaino, N. P. ., Ticoalu, S. H . ., \& W ongkar, D. (2014). Pengaruh Zumba terhadap Kadar Gula Darah. EBiomedik (eBM), 2, 452-458.

Ghani, L. (2009). Seluk beluk menopause. Media Peneliti Dan Pengembangan Kesehatan, XIX, 193-197.

Islami. (2016). Hubungan obesitas dengan siklus menstruasi pada wanita usia subur di desa kaliwungu desa kedungdowo kecamatan kaliwungu kabupaten kudus tahun 2016. RAKERNAS AIPKEMA, 194-197.

Kalangit, A. L. A. (2016). Produk Kesehatan dan Pembentukan Tubuh Perempuan Muda di Kota M anado. Holistik, (17), 1-21.

Kemdikbud. (2016). Peraturan Menteri Pendidikan Dan Kebudayaan Republik Indonesia Nomor 19 Tahun 2016 Tentang Program Indonesia Pintar, 2-5. Retrieved from psma.kemdikbud.go.id

Kurniawan, A. F., Trisetiyono, Y., \& Pramono, D. (2016). Pengaruh Olahraga terhadap Keteraturan Siklus M enstruasi pada M ahasiswi Fakultas IImu Keolahragaan U niversitas N egeri Semarang Tahun 2016. Jurnal Kedokteran Diponegoro, 5(4), 298-306.

Manurung, M. F., Utami, S., \& HD, S. R. (2015). Efektivitas Yoga terhadap Nyeri Dismenore pada Remaja. JOM, 2(2), 1258-1265.

Milanti, I., Fransiska, N., \& Nugroho, H. (2017). Gambaran Faktor-Faktor yang M emperngaruhi Siklus Menstruasi pada Mahasiswi Fakultas Kedokteran Universitas Mulawarman. Jurnal Kebidanan Mutiara Mahakan, 5(1), 1-11.

Noor, S., \& N orfitri, R. (2015). Perubahan Keluhan Gejala Prahaid dengan Senam Aerobic. Jurnal Ners, 10(1), 38-47.

Olivia, F. (2013). Mengatasi Gangguan Haid. Jakarta: PT. Gramedia.

Priani, Ik. F. (2016). Hubungan Status Gizi dengan Siklus M enstruasi pada Remaja Puteri di Prodi D-III Kebidanan Samarinda, $7($ II), 106-114.

Putra, I. G. N. E., Pradnyani, P. E., Pragmaningtyas, M. S., Kusumadewi, N. M. C., \& W idarini, N. P. (2016). Faktor-faktor yang mempengaruhi umur menarche (menstruasi pertama) pada siswi sekolah dasar di Kota Denpasar. BIMKMI, 4(1), 31-38.

Putri, K. A. K., \& Sudhana, H . (2013). Perbedaan tingkat stres pada ibu rumah tangga yang menggunakan dan tidak mengguanakan pembantu rumah tangga. Jurnal Psikologi U dayana, 1(1), 94-105.

Raswin. (2014). Perbandingan perempuan dalam olahraga di Indonesia dengan negara Colombia. Jurnal I/mu Keolahragaan, 13(2), 38-44.

Sianipar, O., Bunawan, N. C., Almazini, P., Calista, N., Wulandari, P., Rovenska, N., ... Suarthana, E. (2009). Prevalensi Gangguan M enstruasi dan Faktor-Faktor yang Berhubungan pada Siswi SMU di Kecamatan Pulo Gadung Jakarta Timur. Maj Kedokt Indon, 59(7), 308-313.

Susanti, E. (2015). Faktor-faktor yang berhubungan dengan gangguan siklus menstruasi pada wanita usia subur di wilayah kerja puskesmas M andiangin Bukit Tinggi tahun 2014. Jurnal Kesehatan STIKes Prima Nusantara Bukittinggi, 6(2), 107-117.

W inarto, N., Djuwantono, T., Permadi, W ., M adjid, T. H., Bayuaji, H., \& Ritonga, M. A. (2007). Kupas Tuntas Kelainan Haid. (M ariyam, Ed.). Jakarta: CV. A gung Seto.

Received: 3 A pril 2020, Accepted : 17 M ay 2020 - M ay 2020 - Jurnal Photon V ol.10 No.2

DOI : https://doi.org/10.37859/jp.v10i2.1892

PHOTON is licensed under a Creative Commons Attribution-ShareAlike 4.0 International License 
Photon

Jurnal Sains dan Kesehatan

E-15SN : 2579-5953 P-15SN:2087-393X

http://ejurnal.umri.ac.id/index.php/photon

Yulianti, S. (2010). Faktor - Faktor yang Berhubungan dengan Kejadian Kanker Fakultas I/mu Kesehatan Universitas /slam Negeri ( UIN ) ALAUDDIN.

Zalmi, R. I., Harahap, H., \& Desfita, S. (2017). Usia Menarche Berhubungan Dengan Status Gizi, Konsumsi M akanan Dan A ktivitas Fisik. Jurnal Kesehatan Reproduksi, 8(2), 153-161.

Received: 3 A pril 2020, Accepted : 17 M ay 2020 - M ay 2020 - Jurnal Photon V ol.10 No.2 DOI : https://doi.org/10.37859/jp.v10i2.1892

PHOTON is licensed under a Creative Commons Attribution-ShareAlike 4.0 International License 